\title{
The Role of Estonian Community Settings for Achieving Independent Living for Persons with Disabilities in Eastern European Countries
}

Vugar Mammadov*

DOI: 10.21827/GroJIL.9.1.128-142

\begin{abstract}
Keywords:
CRPD; ARTICLE 19; INDEPENDENT LIVING; DE-INSTITUTIONALIZATION; CONGREGRATED COMMUTY SETTINGS
\end{abstract}

\begin{abstract}
This article is dedicated to analysing the implementation of Article 19 (paragraphs ' $b$ ' and ' $c$ ') of the Convention on the Rights of Persons with Disabilities (hereby: the CRPD) in community settings in Estonia and how Estonian experiences can shift the development of independent living and deinstitutionalization in other non-European Union member countries of Eastern Europe. In this regard, this article depicts the details of independent living for persons with mental health problems according to the UN CRPD Committee. Furthermore, the introduction of Maarja Küla (village) SA and its role in providing independent living has been highlighted as well. Finally, the primary obstacles in Eastern European countries ahead of establishing an independent living as well as solutions for the implementation of Article 19 are underlined, and as an author, I have emphasized how to foster deinstitutionalization in the conclusion.

In most congregated community settings where organizational management techniques have relied on the medical model of disability rather than the social model of disability, inhabitants suffer from legal incapacitation in most cases. These community settings had been established before the adoption of the CRPD, but gradually have been developed and adjusted to the fundamental principles of the Convention. In my view, a human rights approach has been emerging in such places, though the UN CRPD Committee has urged to rectify management methods and to promote the social model of disability.

This research paper also aims to describe the current situation in community settings that has arisen following the pandemic and to find out scientific and practical solutions to abolish the remaining elements of the medical model of disability and to substitute the human rights approach towards a social model of disability in the management and philosophical views of community settings for persons with disabilities.
\end{abstract}

\section{Introduction}

Before commencing with the gist of the essay, we should first focus on Article 19 CRPD itself. In particular, this essay will look to analyze two paragraphs of Article 19; in this way, advocating for 'living independently' and being included in the 'community of persons with disabilities'. States Parties to this Convention demand to recognize the equal rights of all persons with disabilities to live in the community, with equal choices to others, and take effective and appropriate measures to facilitate full enjoyment for the sake of persons with disabilities and their full inclusion and participation in the community, including by ensuring that:

\footnotetext{
*Vugar Mammadov is a Graduate of the National University of Ireland, Galway with an LLM in International Comparative and Disability Law and Policy; wugar.mamed28@gmail.com.
} 
- Persons with disabilities have access to a 'range of in-home, residential and other community support services, including personal assistance necessary to support living and inclusion in the community, and to prevent isolation or segregation from the community;

- Community services and facilities for the general population are available on an equal basis to persons with disabilities and are responsive to their needs. ${ }^{1}$

Unfortunately, the definition of 'independent living' is not determined in the convention accurately. It can be assumed that this term is not deployed in the narrow sense of performing tasks alone and without assistance. However, the CRPD connects the meaning of independence 'to choice and control' while arranging daily living tasks rather than to unassisted functional ability. ${ }^{2}$ According to the interpretation of Article 19 (b), if a person needs aid, it should be directed to the empowerment of a person for developing their physical existence and inclusion in the community and to reduce 'isolation or segregation from the community. ${ }^{3}$ According to scholarly claimed views, the social model of disability interprets disability as a 'social construct' under discrimination and oppression because it mainly concentrates on an overview of society rather than on individuals. ${ }^{4}$

On the other hand, a precise nomination for settings that can substitute institutions has not been determined yet, usually, it is called either 'community setting' or 'congregated setting'. In my opinion, a legal definition depends on the specific community. Besides that, a principal issue is to focus on 'the will and preferences' of inhabitants. In this way, we should find an answer to the following questions in advance: is this place where they want to live? Have they had a real choice to decide to live in this entity? Are they free to leave based on their will? If the answers to these questions are negative, such settings may be restricting the individual's right to liberty. In this way, the position of Maarja Küla (Maarja Village) has been evaluated from the point of 'community congregated setting' to clarify the purposes of this entity and to give a basic description for readers.

Thus, the first section describes the legal definition of independent living according to the social model of disability as well as the main difference between independent living in the congregated setting or at house setting is emphasized based on Estonian experience.

In the second section, alternatives between community setting and family setting have been compared from the point of Article 19 and Article 25 CRPD. We need to avoid segregation and discrimination based on disability in practical life for persons with disabilities and therefore, we should ensure a certain choice for the best interests of persons with disabilities.

In the third section, the role of individualised support services in community congregate settings are slightly discussed, and social workers in the Maarja Village organization expressed their approach towards distinctions between "in-home" facilities, quality of supplements and services in this village.

In the fourth section, I shared information about Maarja Village and community facilities for persons with disabilities.

1 Barlet Peter, 'A mental disorder of a kind or degree warranting confinement: examining justifications for psychiatric detention' (2012) 16(6) The International Journal of Human Rights 831.

2 Valentina D Fina, Rachele Cera and Guiseppe Palmisano, The United Nations Convention on the Rights of Persons with Disabilities: A Commentary (Springer 2017) 42.

3 European Union Publications Office, Choice and control: the right to independent living: Experiences of persons with intellectual disabilities and persons with mental health problems in nine EU Member States (Luxembourg 2013) 26.

4 Rosemary Kayess and Phillip French, 'Out of darkness into light?' (2008) 8(1) Hum Rights Law Rev 1. 
The following section will examine the possible benefits community congregate settings similar to Maarja Küla SA might have for other disability communities.

In the final section, I have noted my personal views on the advantages and disadvantages of the congregated community settings.

\section{Independent living according to the CRPD and new models of disability}

Disability is observed as a regular difference within the sequence of human variations. In this regard, the social model discerns between impairment and disability. Because the impairment relates to a condition of the body or the mind, disability is the environmental overview which appears as the result of society responding to that impairment. ${ }^{5}$ From a political point of view, the segregation of disabled persons from society is considered as the result of obstacles and exclusion. ${ }^{6}$

The human rights model of disability also rejects segregation by society even though there are several key differences between them. Whilst the social model respectively aims to promote disability, the human rights model implicates values for a disability policy that recognize the 'human dignity' of disabled persons. This model merely elucidates why all persons with disabilities have a right to be legally recognized as a person before the law. Furthermore, the social model does not aim to provide moral principles or values as a foundation of disability policy. According to the interpretation of Article 1 CRPD, the aim of the Convention is "to promote, protect and ensure the full and equal enjoyment of all human rights and fundamental freedoms by all persons with disabilities, and to promote respect for their inherent dignity."

In Article 19, one of the essential targets of the CRPD has been stipulated which comprises, "the full inclusion and effective participation in society for persons with disabilities that require to respect 'freedom of choice' of persons with disabilities, and 'the principle of control' by themselves over their own lives". Besides that, Article 19 also stipulates States Parties to accept legal obligations to respect and facilitate 'full enjoyment of the primary rights of persons with disabilities. ${ }^{8}$ Both the 'social' approach to disability enshrined in the CRPD and the concept of equality (and 'non-discrimination') that underlines the Convention explains the notion and implications of this obligation. ${ }^{9}$

The term 'living independently' in the title of the CRPD, Article 19 does not justify an alleged right of persons with disabilities to be independent, in the sense of living 'a highly individual and self-sufficient life'; namely, a life 'on their own'. Perhaps we can refer to the opinion of one disability studies scholar who observed, "in reality, of course, no one in a contemporary industrial society is completely independent: we live in a state of mutual interdependence', therefore, the dependence of people with disabilities should not be designated as a different personality from the rest of the population." 10

\footnotetext{
Anna Lawson and Caroline Gooding, Disability rights in Europe (1st edn, Hart Publishing 2007) 85-87.

Valentina D Fina, Rachele Cera and Guiseppe Palmisano (n 2) 42.

ibid 43.

Lawrence Gostin and Lance Gable, 'The Human Rights of Persons with Mental Disabilities: A Global Perspective on the Application of Human Rights Principles to Mental Health' (2009) 63 Maryland Law Review, 20.

9 Valentina D Fina, Rachele Cera and Guiseppe Palmisano (n 2) 354-355; See United Nations, Report of the Working Group to the Ad Hoc Committee (2004) A/AC.265/2004/WG/1, Annex I. Final text compiled as adopted (CRP.4, plus CRP.4/Add.1, Add.2, Add.4 and Add.5). See General Comment No. 5 (2017) on living independently and being included in the community.

10 Michael Oliver, 'Disability and dependency: a creation of industrialised societies' in Len Barton (ed), Disability and dependency (Falmer Press 1989) 83-84.
} 


\section{Optional choice: regular family setting or community living?}

We should consider that 'the right to live independently and be included in the community is a relatively 'new' right. In this way, it is difficult to point out the precise indication regarding their optionality. That stipulates importance from the perspective of a proper application of the Convention. This means that the requirement of such recognition would not be satisfied merely by the ratification of the CRPD and the consequential acceptance of Article 19. States Parties should rather provide explicit and formal recognition of the right, principally by including it in their national legislation and rooting it "in a legislative framework which establishes it as a legal right and in changing duties on authorities and service providers, while also allowing for remedy in case of violation." 11

The notion of 'independent living' is profoundly connected to 'personal autonomy', 'freedom to make choices concerning their own life' and 'run one's life and decisions'. Thus, it does not matter whether the right to independent living is breached either in the family or in the community setting. In this sense, the term is compatible with the Preamble to the Convention, which features, "the significance for persons with disabilities of their 'individual autonomy and independence, the right to make their own choices is included as well". The scope of Article 19 simultaneously seizes the principle of Article 3(a) of the Convention; namely, "respect for inherent dignity, personal autonomy including the freedom to make one's choices, and independence of persons." 12

We should also note that Article 19 (c) has similarity with and relationship to other provisions such as Article 9 on 'accessibility' which requires States to pass measures to protect equality for persons with disabilities when they need access to a physical environment, to transportation, to information and communication technologies and systems and to other facilities and services that are openly provided to the public. ${ }^{13}$ We can add to this list: Article 20 on personal mobility; Article 21, in the part concerning access to information; Article 24, para. 2, on education; Article 25 on health; Article 27 on work and employment; Article 28, in so far as social assistance and social protection services, besides, partly Article 30, that concerning cultural and sporting services; and certainly, Article 5 on 'equality and nondiscrimination', specifically para. 3, which requires States Parties to take all appropriate steps to ensure that reasonable accommodation is provided. ${ }^{14}$

One of the decisive issues at stake in Article 19 (a) concerns 'forced institutionalization' and deinstitutionalization. It is well known that high numbers of persons with disabilities all over the world are placed in 'institutions' where they are segregated from their families, communities, and the wider society and where they often suffer under appalling living conditions and human rights abuses. ${ }^{15}$ This is antithetical to the main objective of Article 19 which underlines 'community living' that engages the right of persons with disabilities 'to live, participate, and be included in the community and prohibit segregation or isolation from the

11 Office of the United Nations High Commissioner for Human Rights, Thematic Study by the Office of the United Nations High Commissioner for Human Rights on enhancing awareness and understanding of the Convention on the Rights of Persons with Disabilities (2009) A/HRC/10/48, 51.

12 Michael Perlin, 'International Human Rights and Comparative Mental Disability Law' (2008) Carolina Academic Press, 353.

13 Ruth Townsley, 'The implementation of policies supporting independent living for disabled people in Europe: synthesis report' (2009) Academic Network of European Disability Experts.

14 Ariene Kanter, The Development of Disability Rights Under International Law (Routledge 2015) 134.

15 Office for Europe of the UN High Commissioner for Human Rights, 'Getting a life - living independently and being included in the community' (Office of the United Nations High Commissioner for Human Rights Regional Office for Europe, April 2012) 75-76

<https://europe.ohchr.org/Documents/Publications/Getting_a_Life.pdf> accessed 17 July 2021. 
community'. ${ }^{16}$ A strong presumption that the practice of isolating and segregating people with disabilities in long-term institutions thus contradicts with the scope of Article 19. Nevertheless, such a presumption is amplified by the interdiction interpreted in Article 14 of the Convention. Meanwhile, it does not allow any exceptions based on which persons may be deprived of liberty or detained by their actual or perceived disability, including perceived danger to themselves or others. ${ }^{17}$

In this regard, 'institutionalization' could only be accepted from an abstract and theoretical point of view or in cases in which a person with disabilities would sincerely choose to be a resident of a large or small institution, isolating him/her from the family and the community. However, such a choice would stipulate that real options of dispositions of family and community life that are different from living in institutions have been made compatible to the will of the particular person. ${ }^{18}$ We cannot deduce a conclusion from the meaning of Article 19 (a) as an obligation on States Parties to prohibit institutionalization. Nevertheless, the correct point is to acknowledge and ensure that persons with disabilities should have effective exercise of the right to live independently and be included in the community. In addition, States Parties must commence and proceed forward a deinstitutionalization process by making living arrangement alternatives to be actually available. ${ }^{19}$

In my point of view, 'congregated community centres' are special types of non-profit organizations that play the role of more than just a rehabilitation centre. For instance, typical medical institutions base their functionality on a medical model of disability. However, congregated community centres like Maarja Küla SA are potential institutions that can fulfil the requirements of the CRPD which is based on a social model of disability in terms of providing an independent living.

According to several authors, effective 'deinstitutionalization requires a systemic approach, in which the transformation of 'residential institutional services' is a unique element of substitution in areas such as 'health care, rehabilitation, support services, education and employment, as well as in the societal perception of disability'. ${ }^{20}$ On the other hand, to implement the object and purpose of Article 19 (a), taking all available and measurable steps to carry out the target of deinstitutionalization is a duty of State Parties while displaying all their resources and adopting satisfactory funded strategies with obvious time frames and criteria. ${ }^{21}$

While concluding remarkable concerns about choices in community settings and how far they can substitute family life, I would rather say that it depends on the level of disability and individual choices. For example, in Estonian community settings, inhabitants consider these places as their first homes. However, some of them consider it as a second home for themselves. Nevertheless, there is also a need to conduct rigorous scientific research and to designate precise distinctions between family setting and communities in terms of implementation of independent living, inclusive education and participation in cultural life.

16 See Valentina D Fina, Rachele Cera and Guiseppe Palmisano (n 2) 295: commentary on Article 14 [Liberty and Security of Person].

17 OHCHR, 'On the outcomes and costs of the process of de-institutionalization' (2014) para 25.

18 Valentina D Fina, Rachele Cera and Guiseppe Palmisano (n 2) 370; See Camilla Parker and Luke Clements, 'The UN Convention on the Rights of Persons with Disabilities: a new right to independent living?' (2008) 4 European Human Rights Law Review 508.

19 Jim Mansell et al, Deinstitutionalisation and community living - outcomes and costs: report of a European Study. Volume 1: executive summary (Tizard Centre, University of Kent 2007).

20 Mental Disability Advocacy Center, Litigating the right to community living for people with mental disabilities: A handbook for lawyers (OUP 2014).

21 Jim Mansell et al, Deinstitutionalisation and community living - outcomes and costs: report of a European Study. Volume 2: main report (Tizard Centre, University of Kent 2007). 


\section{Role of Individualised Support Services in Community Congregate Settings}

The guaranteeing role of States towards the enforcement of the right to accommodation reflects the social model of disability that sees disability because of barriers in society rather than a person's particular impairment. Thus, the onus falls on the States Parties rather than the person with the disability to take the necessary steps to ensure compliance with the CRPD. ${ }^{22}$ By contrast, I imply that representative organizations of persons with disabilities and individuals from disability communities should foster recognition of legal capacity not only in the minds of authorities but also in the mind of the whole society. The philosophical establishment of the Maarja Village and other community settings in Estonia consequently looks to change biased approaches towards disabilities in all Eastern European countries.

The conclusion above is moreover confirmed by subparagraph (b) of Article 19, which requires States Parties to ensure that persons with disabilities have access to, "a range of inhome, residential and other community support services, including personal assistance necessary to support living and inclusion in the community, and to prevent isolation or segregation from the community." This is ultimately the second kind of measure precisely contemplated by Article 19 as necessary to be adopted by States to facilitate the enjoyment of the right of persons with disabilities to 'community living' ${ }^{23}$

According to requirements of Article 19(b), the 'naturally occurring community support', that is the form of assistance that is provided informally to persons with disabilities by family, friends, or other members of the community, should also be considered within the support services that States Parties are charged to provide incentives- such as social security benefits, allowances, and pension schemes. ${ }^{24}$

Regardless of the type of measure, a State must guarantee the existence and accessibility of support services, the measure reasons that such services are to be provided as and to the extent that they are significant to support living and being included in the community and to prevent isolation or segregation from the community'. ${ }^{25}$ Nevertheless, support services include 'home assistance' with self-care and housekeeping. But, 'in-home assistance' should not be intended and applied to, "prevent a person from leaving the home when he or she desires and should be complemented, where needed, by other communitybased services." 26

According to several authors, ensuring that non-discrimination is the major principle in all areas of society aligns with the seven other leading principles in Art. 3 of the Convention. Nevertheless, it is considered a firm foundation to establish within the conditions of the implementation of civil and political rights. However, 'the non-discrimination policy' must always be followed up by assertive measures, improving perspectives of the independent living, inclusive education and employment on the regular labour market. ${ }^{27}$

As for all other citizens, three leading issues will repudiate all others when it comes to inclusion in contemporary society for persons with disabilities:

22 AS Kanter, The development of disability rights under international law from charity to human rights (Routledge 2015) 855-856.

23 Oliver Lewis and Genevra Richardson, 'The right to live independently and be included in the community' (2020) 69 IJLP; 'The Statement of the Committee on the Rights of Persons with Disabilities on article 14' (issued at the 12th Session of the Committee, CRPD/C/12/2) 14.

$24 \mathrm{OHCHR}$, Thematic study on the right of persons with disabilities to live independently and be included in the community (2014) A/HRC/28/37, para 29.

25 OHCHR (n 17); General comment No. 5 (n 9) paras 16 (a), 16(b), 16 (c)

26 General comment No. 5 (n 9) 30.

27 Marianne Schulze, Understanding the UN Convention on the Rights of Persons with Disabilities (2nd edn, Handicap International 2010) 113-116. 
- 'Schooling and education,

- 'Work and employment and

- 'Health'. ${ }^{28}$

Maarja Village provides its inhabitants with education and employment within the community. However, this is segregated education and employment of inhabitants apart from the society.

Equal opportunities in these three aforementioned sectors are essential. Meanwhile, for persons with disabilities ,the following three preconditions for inclusion are equally necessary:

- 'Habilitation and rehabilitation,

- 'Accessibility' and

- 'Personal mobility'. ${ }^{29}$

In Maarja Village, habilitation and rehabilitation services are organized for persons with disabilities and accessibility is provided as far as possible to help inhabitants to accelerate their mobility as well.

\section{Practical implementation of Article 19 according to the UN CRPD Committee}

Disability rights defenders most of all promulgate to enhance efforts towards deinstitutionalization. The enunciation and implementation of national plans for the prohibition of 'residential institutions' as well as to take on fairly funded strategies have been challenged by the UN CRPD Committee for deinstitutionalization. Furthermore, it has also been stressed that policy processes for deinstitutionalization should have "a clear timeline and concrete benchmarks for implementation which are effectively monitored at regular intervals." 30

We should also note that besides the requirement on changing policies and measures for the sake of implementing, 'community support services must allow adults with disabilities to live independently on their own accord. Therefore, the Committee has envisaged States Parties to "involve disabled persons' representatives and their families in their tutoring process." 31

In my opinion, deinstitutionalization itself requires providing accessibility to persons with disabilities with regard to public services in their daily lives. The interpretation of 'inclusiveness and accessibility to public services' as per the scholars covers essential services and facilities provided for in the society and concerns, such as by providing health, vocational education and training, and support in finding employment, social assistance, housing, transportation, information technologies and so on. In addition, Article 19 (c) relates to other

28 Valentina D Fina, Rachele Cera and Guiseppe Palmisano (n 2) 367; Committee on the Rights of Persons with Disabilities (n 23) paras 30-32.

29 Valentina D Fina, Rachele Cera and Guiseppe Palmisano (n 2) 368; Clíona de Bhailís and Eilionóir Flynn, 'Recognising legal capacity: commentary and analysis of Article 12 CRPD' (2017) 13(1) International Journal of Law in Context 6, 9.

30 Committee on the Rights of Persons with Disabilities, 'Concluding observations on Australia' (2013) CRPD/C/AUS/CO/1, para 42; See CRPD Committee, 'Concluding observations on Azerbaijan' (2014) $\mathrm{CRPD} / \mathrm{C} / \mathrm{AZE} / \mathrm{CO} / 1$, para 33; See CRPD Committee, 'Concluding observations on Belgium' (2014) CRPD/C/BEL/CO/1; See CRPD Committee, 'Concluding observations on the initial report of Germany' (2015) CRPD/C/DEU/CO/1, para 42.

31 CRPD Committee, 'Concluding observations on Belgium' (2014) CRPD/C/BEL/CO/1, para 33; CRPD Committee, 'Concluding observations on China'(2012) CRPD/C/CHN/CO/1, para 32. 
provisions of the Convention, such as Article 9, Article 20; Article 21, Article 24 (2), Article 25 on health, Article 2, Article 28 and so on. It should be emphasized that Article 19 (c) requires States to ensure not only that public services are available on an equal basis to persons with disabilities but also that they are retaliatory to their needs. ${ }^{32}$ On the other hand, to make it responsive, it will require the representatives of disability organizations to be principal decision-makers who in addition have the right to participate in the planning, development, and implementation of State policies and measures on the subject of accessibility to publicly established services. ${ }^{33}$

To sum up, congregated community settings with representatives of disability organizations should make partnerships with academic institutions and business associations to promote independent living for persons with all types of disabilities as far as possible. Social workers in Maarja Küla SA claim that to enforce full independence for all types of persons with mental health disabilities because of prejudice and perhaps due to their inabilities in certain situations. According to their views, the role of community settings should be an intermediary, namely, we can only connect a person with disabilities with an employer who is looking for cheap products. Unfortunately, in vulnerable cases, employers abuse their cheap workforce to gain more profits. In my view, we should look over the improvement of independent living not only in the context of Article 19, but with other provisions of the CRPD, such as Article 23, Article 24, and Article 30. Maarja Village and other similar communities in Estonia pay attention to Article 30, which tries to provide public facilities to foster participation in cultural and sports activities for their inhabitants. For example, although there is a sports day or circus day out of each week for inhabitants in Maarja Village, it does not mean that they are independent since it is a daily obligation that inhabitants must fulfil every time. Therefore, arbitral procedural community rules prevent achieving full independence for inhabitants as well.

\section{Introduction to Maarja Küla SA. It's a role for providing independent living}

Maarja Küla as an organization was founded by Tartu Toome Rotary Club and by Tartu Maarja School on April 7, 2001 to establish a 'home' for persons with intellectual disabilities all over Estonia. There are two essential goals of this organization: the first target is to inform society about the existence and nature of people with intellectual disabilities and the social shortcomings related to their way of life in Estonia. At the same time, providing development and employment opportunities for young people with intellectual disabilities is the second purpose. In this way, the Maarja Küla SA ('kula' means village in Estonian) as an NGO is a community in Southern Estonia, it is home to adults with intellectual disabilities who can enjoy a satisfying and meaningful daily and working life within a community. ${ }^{34}$ The people living in the village are not considered customers but residents who organize their living arrangements. Working family members also live with them to facilitate them to cope better in case of need.

This organization stands for supporting the right of people with intellectual disabilities to full life activities and resources. Maarja Küla tries to remain as an independent and economic unit as much as possible. Nevertheless, the offered services in Maarja Küla are implemented by professionals from different fields, and services are gradually developed.

32 Maya Sabatello and Marianne Schulze (eds), Human rights and disability advocacy (University of Pennsylvania Press 2014) 209.

33 Human Rights Council, 'Report of the Special Rapporteur on torture and other cruel, inhuman or degrading treatment or punishment' (2013) A/HRC/22/53, para 26.

34 'Homepage' (Maarja Küla) <https://maarjakyla.ee/> accessed 17 July 2021. 
This organization embraces these values are noted below:

- Everyone is a value;

- Caring and respect;

- Everyone is capable of development;

- Openness;

- A sense of security;

- Cooperation;

- Nature friendliness and awareness. ${ }^{35}$

Maarja Küla (village) rejects the internal hierarchy for people with special mental needs within the community and members of the family have equal rights, they have been provided with proper safe work, working facilities, and areas of responsibility varying according to ability. Besides that, Maarja Küla is a multicultural organization where people are not discriminated against or distinguished because of their origin, religion, social background, sexual preferences or any type of biological or social varieties. This organization is open to new ideas, activities and people. Members of the organization should learn, explore and find ways to turn our ideas into reality. This organization promotes social entrepreneurship, they provide forward-looking feedback with the help of acting, and instructions.

Interviews with two officials of Maarja Küla SA have been conducted to investigate problems of deinstitutionalization in Estonia, and this organization's role for the sake of providing an independent living. This interview is based on six precise questions. The first question was about assessing the role of Maarja Küla SA in providing accessibility for inhabitants, namely, in terms of the implementation of Article 9 CRPD. They briefly answered that Maarja Village has created accessibility to physical facilities for all inhabitants regardless of the type of disability, age or gender. Workshops and living houses are easily accessible, besides that, by the sponsorship of the 'Philip Morris' help, a wheelchair footpath to the forest has been set up too, thus, inhabitants who need physical help during their daily life have the opportunity to get personal assistance from house assistants. Besides, internet access is provided to all inhabitants who can then express their interest.

The second question was: 'How far community living habits can substitute regular family life for adult inhabitants within conditions of the Maarja Küla SA?' According to representatives, their inhabitants (clients) are all grown up individuals with learning disabilities. They have all the rights to live a regular family life. When planning living houses, we took into consideration that there might be inhabitants who would like to live a regular family life - so we planned some rooms bigger than others. State service 'living in the community' that is provided in Maarja Village, has five areas of support:

- Time planning;

- Free time activities;

- Using public services;

- Helping with studies;

- Helping with work or other types of labour activities.

Respondents accentuated that regular family life requires responsibility from grown-up family members, but authorities do not require service providers to give support towards family life. The main goal of the service is to preserve and develop people's everyday life skills, so that he/she could manage their lives as independently as possible in the community environment. In Maarja Village, administrators have created groups for inhabitants who would like to discuss different topics. These groups have been developed by specialists of our rehabilitation

35 'What is Maarja Küla' (Maarja Kula) <https://maarjakyla.ee/maarja-kula/> accessed 17 July 2021. 
team. Topics include friendship, family, sexuality, community. When inhabitants need more support on these topics, rehabilitation specialists continue with individual work.

Representatives have also stressed that there are key details of 'the person-centred approach in Maarja Küla:

a) Personal profiles and developmental plans, weekly plans of work. Inhabitants can change their plans if they like to, plans have always been created by inhabitants presence;

b) Comparing to state service, in Maarja Village there are more assistants per person than service requires;

c) Rehabilitation plans have been made in spirit to develop personal skills in areas that lead inhabitants to a more independent life and widen their possibilities to be an equal member of society.

In the interview, they evaluated perspectives which they consider distinctive elements of living in Maarja Küla from institutional care. According to their responses, the Maarja Village identifies itself more as a regular Estonian village than an institution. For example, a public bus stop activates in the centre of the village, where daily buses from Põlva to Tartu move every day. Inhabitants live in their family houses like they would live anywhere else in society. The main difference would be that here they can use individual support more frequently. There are also some volunteers from abroad who live in Maarja Village with inhabitants. Their task is also to support village inhabitants in everyday life. Volunteers' presence makes a lot of difference in the village's environment through the creation of community life which would be impossible under institutional restrictions.

To the question of what kind of benefits Maarja Küla offers regarding: 'selfdetermination and choice'; 'personal and family satisfaction; 'skills development' and 'quality of life: the respondents highlighted that the main principles of villages point out no difference between inhabitants and workers in terms of rights and possibilities Inhabitants are allowed to visit the rehabilitation team regularly during the meetings where they share their thoughts and point of views with the specialists. In every house, there are supportive persons as house assistants who work and live together with inhabitants with the goal of creating a bond where inhabitants are free to share their deepest wills. The rehabilitation team, house assistant and inhabitants create developmental plans together for inhabitants where they mark down goals and choices (long term) from the inhabitants' point of view.

Inhabitants are also included in village life and development. For example, every Monday there are village meetings where village life and development is being discussed. Inhabitants have a right to add their suggestions to improve their life and life in the village in general. Since the beginning of the village, personal development and 'quality of life' have been top priorities for the Maarja community. According to Ly Milkheim and Huko Laanoja: 'We have created a physical environment of work, free time and study that includes workshop buildings, free time facilities, possibilities for personal space'. Additionally, the rehabilitation team of the village, which is dealing with the questions of 'skill development' and 'quality of life' of the people who live there, but also for the disabled persons who do not live there but are merely visiting the village as clients. ${ }^{36}$

The last question was to determine what kind of challenges they foresee regarding 'deinstitutionalization in Estonia. According to experts, wrong decisions from authorities who have precise information and policy concerning the living of persons with learning disabilities is at the forefront. Therefore, the Estonian government should figure out a general

36 Interview with Ly Milkheim and Huko Laanoja on 12 May 2020. 
approach of disability rights organizations towards the deinstitutionalization process and what it actually means from the point of independent living.

In my opinion, we should first evaluate the significance of community settings like the Maarja Küla from a point of equal recognition before the law and effective participation in society. Article 19 is to call on States parties to 'recognize' the equal right of all persons with disabilities to reside in the community with choices 'equal to others.' This right requires banning confining high-functioning persons with disabilities or by excluding sub-groups such as those with intellectual or psychosocial disabilities, those with 'high dependency needs' or those who have 'dangerous behaviour'. It is more convenient for States to extend this right first to those who are 'high functioning'. However, Article 19 does not abandon the 'low hanging dependency' either, therefore, its normative reach is included to all categories without exception, in addition, States must take 'effective and appropriate measures to facilitate 'full enjoyment of the right. ${ }^{37}$ In my opinion, while highlighting the definition of 'independent living' we should focus on the notion of 'home' in advance. Medical treatment in psychiatric institutions emanated from a medical model of disability, perhaps, an institution can never substitute 'home' for persons with intellectual disabilities. ${ }^{38}$

From the point of Article 19(a), the notion of a 'home' has been characterized as the 'materialisation of identity' by scholars. According to their approach, it is a physical space that ramifies one's 'personhood', reflects it and provides an auspicious and safe environment for the flourishing of 'personhood' ${ }^{39}$ Furthermore, the home provides a place of repose where the individual can be excluded from the world and, in interaction with 'family and friends and other intimate acquaintances 'develop one's identity' and how an individual approaches the society. The notion of a 'personal privacy'(or 'the reasonable expectation of privacy'), however, seems to be at its most significant when an individual is confined inside the home.

While disclosing the definition and requirements of Article 19, an interesting topic emerges when we discuss the reason behind deinstitutionalization, and how far it is appropriate and effective from the point of the state policy and the CRPD. In this regard, the literal statement of Article 19 calls on States to take 'effective and appropriate measures' to facilitate 'full enjoyment' of the right. However, 'effectiveness' is also affiliated with 'the subjective experience' of the individual. Replacing large institutions with smaller ones will not necessarily be beneficial if the main functional characteristics of larger institutions are not renovated. Therefore, banning large institutions in favour of 'group homes' may not certify being 'effective and appropriate' when imitation remains. In particular, the obstacles to associate the individual, namely, 'qua individual'- to the community are not labelled, meanwhile, the establishment of 'appropriateness' is subject to evaluating the quality of the adopted measures and specifically if they suitable with the outspokenly expressed 'wishes and preferences of the individual. ${ }^{40}$

The practical implementation of deinstitutionalization policy requires 'effective and regular' monitoring with the help of utilization of firm standards and 'measurable human rights-based indicators'. Besides that, budgetary assignments for the progress of community services should follow this implementation process too. ${ }^{41}$ In several cases, the CRPD Committee had revealed that despite commitments towards deinstitutionalization, states parties have continued to invest resources for constructing, renovating, and enlargement of institutions. However, Article 19 does not forbid renovating institutions if reasonable balance

37 Office for Europe of the UN High Commissioner for Human Rights (n 15) 26.

38 ibid, 27;Clíona de Bhailís and Eilionóir Flynn (n 29) 11-12.

39 Iris Young, 'House and Home: Feminist Variations on a Theme' in Dorothea Olkowski (ed), Resistance, Flight, Creation: Feminist Enactments of French Philosophy (Cornell University Press 2000) 63.

40 Camilla Parker and Luke Clements (n 18) 26.

41 CRPD Committee, 'Concluding observations on the initial report of Kenya' (2015) UN Doc $\mathrm{CRPD} / \mathrm{C} / \mathrm{KEN} / \mathrm{CO} / 1$, para 38 . 
must be protected between rival policy objectives. ${ }^{42}$ In this way, it seems that authorities in not only EU countries but also in the rest of the world are not voluntarily willing to abolish psychiatric institutions, probably, the representatives of , authorities who make decisions on behalf of the disability rights lawyers and health practitioners do not have basic knowledge concerning the social model of disability.

\section{Counterargument: what advantages or disadvantages do institutions like Maarja Küla SA can impose on States}

Despite the ultimate prohibition of psychiatric institutions by the Convention, we can envisage the provisional benefits of the social institutions that exist in Estonia. Unfortunately, psychiatric institutions continue to serve in several countries. Meanwhile, several countries have adopted deinstitutionalization within a policy that enables adults with disabilities to abandon institutions and to settle down in the community. The disability rights organizations which supported deinstitutionalization have achieved to revise not only the place of treatment inside a community, but they could also change certain 'clinical aspects of treatment' too. ${ }^{43}$ In this respect, Arlene S. Kanter noted that 'Custodial care of the poor and insane' has been avoided, while medical professionals apply psychotropic drugs to 'maintain' inhabitants in the community. In addition, although having funding concerns about the escalating costs of institutions, new reformed NGOs provided the necessary impact for the development of 'community-based alternatives' to institutions for people with disabilities in particular countries. ${ }^{44}$

Unfortunately, some community housing programs for people with disabilities have been harmful. Meanwhile, 'community living arrangements' were developed as alternatives to institutions based on the notion that housing and services should be offered together, as is done in institutions. Experts usually refer to it as the 'linear model' or the 'continuum of care model' and this model requires that persons with needed services must be sent to specific 'community living' settings. ${ }^{45}$ Thus, to receive the care or rehabilitation services, a person with a disability must move out of his or her own home and must be provided with a room inside a congregate living setting that provides support services. ${ }^{46}$

Article 19 is necessarily connected to Articles 12 and 8 of the CRPD. In this regard, scholars presume that personal development can only exist when 'equal recognition before the law' (article 12) as well as 'awareness and receptiveness to the rights of people with disabilities (Article 8) are inevitably provided. Article 12 stipulates the fundamental right of persons with disabilities 'to exercise their legal capacity on an equal basis with others. Meanwhile, Article 19 (a) CRPD, as well as article 3(a) embarks on 'individual autonomy' ${ }^{47}$ Individual autonomy is tightly affiliated with 'the right to legal capacity' essentially because recognition before the law is one of the decisive elements for making decisions not only regarding 'the place of residence', but also it gives the right to choose with whom to live in a particular house. 'Incapacitation' is one of the primary violations of displaying choice under

42 CRPD Committee, 'Concluding Observations on the initial periodic report of Hungary' (2012) UN Doc CRPD/C/HUN/CO/1; and UN CRPD Commentary: F.B.Janos.

43 Donal McAnaney, 'Active inclusion of young people with disabilities or health problems' (2012) Eurofound, 56.

44 Michael Stein and Penelope Stein, 'Beyond Disability Civil Rights' (2007) 58(6) Hastings Law Journal 1203.

45 Rosemary Kayess and Phillip French, 'Out of Darkness into Light - Introducing the Convention on the Rights of Persons with Disabilities' (2008) 8 Hum Rts L Rev 1.

46 Camilla Parker and Luke Clements (n 18) 26.

47 Arlene Kanter, 'The Promise and Challenge of the United Nations Convention on the rights of Persons with Disabilities' (2007) 34 Syracuse J Int'1 L \& Com 287. 
paragraph (a). Contrarily, General Comment No 5 requires guaranteeing 'the right to legal capacity', which is one of the essential obligations of state parties.

The Maarja Küla SA is an alternative institution to psychiatric institutions that enable persons with various mental health problems to rehabilitate themselves and to protect their autonomy. Besides incapacitation, the CRPD Committee has identified several practices and tools that can restrict the choice of persons with disabilities under Article 19(a); for example: directly sending persons to institutional care, or forcibly relocating them to institutions. ${ }^{48}$

Another most encountered limitation of choice by the state while disallowing the development of alternatives to institutions, in this way, authorities apply overcomplicated licensing processes for the private and non-profit sector, perhaps, it causes dominance of residential institutions. ${ }^{49}$ Scholars also acknowledge that instead of remaining passive, the State's role is to overcome social, cultural and authoritative barriers. ${ }^{50}$ The UN CRPD Committee also included all aspects of a person's living arrangements in the "General comment No. 5 (2017) on living independently and being included in the community", such as one's daily schedule and routine, 'lifestyle', to personal choice, hereby, persons with disabilities must enjoy an effective network of options to enable them to exercise rights as established by article $19 .^{51}$

Besides the aforementioned advantages of Maarja Küla SA and other similar organizations in Estonia, we can see some adversary elements of this organization to the CRPD standards. Article 19 rejects institutions and 'segregated places' because these entities compel control over the daily decisions of inhabitants and are inconsiderate to their individual preferences. ${ }^{52}$ The "General comment No. 5 (2017) on living independently and being included in the community" emphasized that institutions are not determined by size, however, particular crucial elements cause disengage of individual choice and 'personal autonomy' as a result of the enforcement of certain means of subsistence and maintenance. ${ }^{53}$ The right to choose is undoubtedly the core of article 19 and 'independent living' is hardly possible in isolated institutions or in 'congregated care facilities', because, such enterprises often restrict opportunities to make choices, besides that, psychiatric institutions based their offer on a 'fixed program' without verifying whether an inhabitant wants to live or to work in a particular place. ${ }^{54}$

While taking into account the requirements of the CRPD Committee concerning the definition of institutions, we can compare institutions with community settings likewise Maarja Küla we can claim that this community setting is located in a remote area covered with forests, and most citizens might not be aware of its existence. Unfortunately, because of poor transportation and for its far location inhabitants do not always have access to communication and making friends from outside. However, we should also take into account that non-disabled persons do not have all facilities to make friends with their peers, especially in a small country such as Estonia, that's why, from my point of view segregated location should not be a serious reason for disqualification, nevertheless, this a special type of scientific question which is difficult to evaluate without broader academic and practical investigation.

'Loss of choice' is the sensitive side of Article 19 can happen also in congregate care but hardly occurs in individualized support, however, there is a need to enable inclusion in

48 CRPD Committee, 'Concluding observations on the initial report of Belgium' (2014) UN Doc CRPD/C/BEL/CO/1, para 32; CRPD Committee, 'Concluding observations on the initial report of Denmark' (2014) UN Doc CRPD/C/DNK/CO/1, para 42.

49 Tom Shakespeare, Disability Rights and Wrongs (Routledge 2006) 32.

50 ibid, supra note 127 , at 102.

51 CRPD General Comment No 5 (n 9) paras 24,25.

52 Rosemary Kayess and Phillip French (n 45) 292, see supra note 89; Paul Harpur, Discrimination, Copyright and Equality: opening the e-book for the print-disabled (Cambridge University Press, 2017) 46.

53 Rosemary Kayess and Phillip French (n 45) 292, see supra note 89.

54 ibid. 
the person's home or inside 'supported individualized apartment' ${ }^{55}$ The Committee validated that probable violation of 'independent living' might occur even in the persons' family home when a shortage in services causes segregation and being concealed in the family. ${ }^{56}$ Therefore, we cannot justify obstacles and regulations that are appeased by authorities for persons who need support in a way in which people without disabilities are not regulated. On the other hand, a choice has direct relevance to the methods of provided support and is related to the existence of options.

To sum up, we should reckon and comprehend what else community settings like SA Maarja Küla can bestow upon something from its' experience. While comparing the benefits of this setting, we should take into account that they provide security, and prevent unnecessary interference in the private life of persons with disabilities which is also protected by Article 8, the European Convention on Human Rights 1950. The ECtHR has prohibited arbitrary interference of authorities, such as mandatory medical treatment. However, community setting is poor to defend a person with disabilities when he/she is arbitrarily taken to the medical institution under the aim of 'to protect health' if a family member or guardian asks for a court about it, despite that the Court has tried to reduce such tendency in Shtukaturov vs Russia (2008) case, nevertheless, the domestic laws in Estonia and other neighbour countries are not enough liberal and positive in terms of personal freedom of persons with mental health impairments. In this way, there is a need to conduct long-term scientific research to enhance the role of community settings for replacing substituted decision-making with the supported decision-making mechanism.

\section{Conclusion}

While discussing the advantages and disadvantages of congregated community settings in Estonia such as Maarja Küla SA, we can suggest that this experience can be the model to emulate in countries lacking individualised support in institutions. Some experts claimed that the absence of 'community-based services' is significant for States' to abide by Article 19 as people with disabilities have limited choices regarding their place of residence. This is particularly a widespread problem in countries where institutional and congregate care entities are dominant. ${ }^{57}$ Although Article 19 does not tackle deinstitutionalization, its text makes it clear that the closure of institutions is required, together with the development of community-based alternatives. Article 19 emphasizes full inclusion and participation in the community, which can only be achieved when there are no more institutions. As General Comment No 5 makes clear, any support service provided by an institutional form that segregates and limits personal autonomy is not permitted by Article 19(b). ${ }^{58}$

I should also emphasize that the Estonian experience might have convergence and a model law for other countries of Eastern and Central Europe such as Azerbaijan. However, to foster deinstitutionalization and to promote the development of community settings that preserve independent living of persons with mental disabilities, there must be trust between family members or representatives of persons with disabilities.

Unfortunately, the supported decision-making has not been effectively established in these countries as a legal institution. Therefore, consent of family members or guardians is required primarily when moving out inhabitants from institutions to community facilities. On

55 Rosemary Kayess and Phillip French (n 45) 296, see supra note 89.

56 CRPD Committee, 'Concluding Observations on the initial report of Gabon' (2015) UN Doc $\mathrm{CRPD} / \mathrm{C} / \mathrm{GAB} / \mathrm{CO} / 1$, para 44.

57 Jim Mansell et al (n 21) 26.

58 Maria Pallisera, 'The role of professionals in promoting independent living: Perspectives of self-advocates and front-line managers' (2018) 31(6) Journal of Applied Research in Intellectual Disabilities 1103. 
the other hand, I stipulate that it is also important to note authorities in post-communist Eastern European countries are not likely to shut down all institutional settings and fully transfer to community facilities. However, Azerbaijani the Psychiatric Act 2011 still encompasses the medical model of disability, and there is still no development of the deinstitutionalization. ${ }^{59}$

In conclusion, the promotion of independent living requires to have a legal capacity for reform that enables incapacitated persons with mental health problems to make decisions on their behalf regarding their legal concerns. In an actual situation, it is difficult to posit exoneration or to condemn adjudication advantages or disadvantages of congregated community settings for the ameliorating position of persons with disabilities. There is an ultimate need to conduct rigorous research regarding the theoretical and practical challenges of these communities in Eastern European countries to find out obstacles to independent living, supported decision-making and so on. The most convenient model law would have been to repeal guardianship utterly, and to bring forth the formal supported decision-making mechanism in community settings of Eastern European countries including Estonia. In Maarja Village, social workers try to play an informal part in the assisted decision-making, as the Estonian government has not recognized formal support services. In my opinion, it is too early to talk about formal support services, because informal supported decision-making has commenced to be applied recently, we need more time and long practice to start developing 'sprouts' of the official supported decision-making in community settings. There is an urgent need to establish an official support service to foster participation in cultural life for inhabitants with disabilities. 